\title{
非熱凝固性卵白液の経腸栄養剤としての利用
}

\author{
西 川善 之*,** \\ * 甲子園大学栄養学部 \\ ** 生産開発科学研究所食品工学研究室
}

\section{Utilization of Non-Thermal-Coagulating Protein of Egg White for Enteral Hyperalimentation}

\author{
Yoshiyuki NISHIKAWA*,** \\ *Department of Nutrition, Koshien University, Takarazuka, 665 \\ ** Department of Food Science and Technology, \\ Research Institute for Production Development, Kyoto, 606
}

\begin{abstract}
Nippon Eiyō Shokuryō Gakkaishi (J. Jpn. Soc. Nutr. Food Sci.) 38, 371 376 (1985)
We have studied the possibility to use a heat stable protein of egg white in enteral hyperalimentation. At first, the egg white protein solution was found to become turbid or to coagulate on heating at $100^{\circ} \mathrm{C}$ in the presence of $\mathrm{Ca}^{2+}$. We have developed an egg white protein solution which did not coagulate on heating even in the presence of $\mathrm{Ca}^{2+}$. The egg white solution, which coagulated at $\mathrm{pH}$ 7.0, became non-coagulative at $\mathrm{pH} 9.0$ even when the autoclaving time in the preparation of the TEW (treated egg white) solution was extended from the conventional time $(10 \mathrm{~min})$ to 60 or $120 \mathrm{~min}$. Further, the TEW solution autoclaved for $120 \mathrm{~min}$ was made non-coagulative at $\mathrm{pH} 7.0$ by using calcium glycerophosphate in place of $\mathrm{CaCl}_{2}$ as the calcium source. Next, the solution of enteral hyperalimentation containing all of the five nutritional components was prepared by mixing the TEW solution, calcium glycerophosphate and the other nutrients. A clear and nutritionally complete solution without the thermal coagulation was finally prepared. Accordingly, the non-thermal-coagulating protein of egg white is expected to be widely useful, not only for enteral hyperalimentation, but also for other foods, such as egg white drink, or for the microbiological industries.

(Received March 11, 1985)
\end{abstract}

著者らは,これまでに鷄卵白の食品産業界等への利用 法を開発する目的で，卵白の熱凝固性低下または消失に 関する研究を行なってきだ) を添加してもまったく熱凝固しない卵白液を得ることに 成功した。そこで本非熱疑固性卵白液を用いて経腸栄養 版としての利用性を検討した。もとより経腸栄養剤は 5 大栄養素を理想的な割合で含む完全栄着剤であるととも に，経管，経口供与（細いチューブ内を通過）のために， 流動性の高いことが必須の条件である。このタンパク源 として従来より牛乳や大豆のタンパク質がおもに利用さ れてきたが，卵白は栄養価が高いにもかかわらず，ほと んど利用されていない現状にある。これは卵白のもつ強 (熱凝固性(3) に起因しており，加熱殺菌することが不

* テ665 宝塚市紅葉ケ丘 10-1

** 个606 京都市左京区下鴨森本町 15
可能であったためと思われる。一方，本非熱凝固性卵白 液はナトリウムイオン $\left(\mathrm{Na}^{+}\right)$飞対しては熱凝固しない か，その後の研究でカルシウムイオン $\left(\mathrm{Ca}^{2+}\right)$ に対して は加熱することにより白濁または凝固することがかかっ た。そこで今回はカルシウム塩類の添加によっても熱凝 固しない条件を見いだすことを目標に研究を進めた。そ の結果，本条件をそなえた経腸栄養刘の標品を調製する ことができたので報告する。

\section{実 験 方 法}

\section{1. 非熱装固性卵白液の調製法32}

卵白液を水で数倍（3～5 倍）に希积し，粯䢁後生じ た釆状の凝集物をろ過除去し，ろ夜についてオートクレ ーブ $\left(120^{\circ} \mathrm{C}\right)$ を 5 120 分行なった。本溶液を以後便宜 上, 非熱凝固性㽗白液 (TEW : 処理 卵白液 (treated egg w.hite) の略）と称する。 
Table 1. Effect of autoclaving time on thermal coagulation in the presence $\mathrm{Ca}^{2+}$ $\left(\mathrm{H}_{2} \mathrm{O}\right.$ treatment).

\begin{tabular}{cccccccc}
\hline \hline \multirow{2}{*}{$\begin{array}{c}\text { Autoclaving } \\
\text { time (min) }\end{array}$} & \multicolumn{3}{c}{$\mathrm{pH} \mathrm{9.0}$} & & \multicolumn{3}{c}{$\mathrm{pH} \mathrm{7:0}$} \\
\cline { 2 - 3 } & Control & $\mathrm{Ca}^{2+*}$ & $\mathrm{Ca}^{2+}\left(100^{\circ} \mathrm{C}\right){ }^{* *}$ & & Control & $\mathrm{Ca}^{2+*}$ & $\mathrm{Ca}^{2+}\left(100^{\circ} \mathrm{C}\right)^{* *}$ \\
\hline 5 & - & + & + & - & + & + \\
10 & - & \pm & + & - & \pm & + \\
20 & - & - & + & - & - & + \\
30 & - & - & \pm & - & - & + \\
60 & - & - & - & - & - & + \\
120 & - & - & - & - & - & + \\
\hline \hline
\end{tabular}

* $\mathrm{CaCl}_{2}$ was added to the solution.

** $\mathrm{CaCl}_{2}$ was added to the solution and heated at $100^{\circ} \mathrm{C}$ for $5 \mathrm{~min}$.

The egg white $(300 \mathrm{ml})$ was diluted with water by five fold, and stirred with a glass rod for $5 \mathrm{~min}$. Fibrous coagulate was filtered with a filter paper. The filtrate was autoclaved for 5 to $120 \mathrm{~min}$, cooled and adjusted to $\mathrm{pH} 9.0$ or $7.0 . \mathrm{CaCl}_{2}\left(\mathrm{Ca}^{2+}: 0.05 \%\right)$ was added to the solution, and heated at $100^{\circ} \mathrm{C}$ for $5 \mathrm{~min}$. In this table, the evaluations $(+,-)$ of the output of coagulate were done by observing the turbidity or measuring the dry weight of the precipitate after filtration as shown below.

[Thermal coagulation test]

H, Strongly coagulated (ppt : over $60 \mathrm{mg}) ; \quad+$, coagulated (ppt :20-60 mg); \pm , turbid (ppt : 5-

$20 \mathrm{mg}$ ); -, clear (ppt : under $5 \mathrm{mg}$ ).

\section{2. 卵白液の熱凝固性テスト（thermal coagulation test)}

種々の条件で調製した卵白液（5 倍に卵白夜を希釈 : $50 \mathrm{ml}$ ) を湯浴中で $100^{\circ} \mathrm{C}, 5$ 分間加熱を行ない熱凝固 性を検討した。判定はサ，十，士，一の 4 段階で評価 し, 判定基準については Table 1 に記載した。

$$
\text { 結果 }
$$

\section{1. カルシウムイオン $\left(\mathrm{CaCl}_{2}\right)$ 存在下での凝集物の生 成と熱疑固性}

まず $\mathrm{Ca}^{2+}$ の存在下でも熱凝固しない条件を見いだす ことを目標に，オートクレーブの加熱時間を変えて検討 した (Table 1)。TEW 液に $0.05 \% \mathrm{Ca}^{2+}$ を添加したと

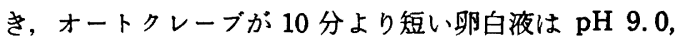
pH 7.0 いずれも白濁または沈殿物が生じたが，20 分以 上のものでは白濁しなかった。しかしこれを $100^{\circ} \mathrm{C}, 5$ 分間加熱すると $\mathrm{pH} 9.0$ では 30 分のものまでは熱凝固 したが，60 分以上では凝固しなかった。一方， $\mathrm{pH} 7.0$ の場合には加熱により 120 分オートクレーブのものも熱 凝固した。一般に TEW 液を調製する際に，水希釈の代 わりにェチルアルコール (10\% EtOH) を用いると, よ り透明な卵白液が得られる゙๋。そこでェチルアルコール 希釈法を試み， $\mathrm{Ca}^{2+}$ による熱凝固性の低下，消失につ いて検討した。その結果, 水希积の場合とほとんど同じ 結果となり, 予想に反しェチルアルコールの効果は認め られなかった。次に生卵白液の倲結融解法による変性処 理を行ない，熱凝固性に及ぼす影䇺を検討した。Table 2 は凍結卵白を $4^{\circ} \mathrm{C}$ から $40^{\circ} \mathrm{C}$ の条件で融解させ, 本卵
白液を水希釈, ェタノール希釈の 2 群に分け, 60 分間オ

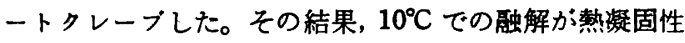
低下には最も好ましいことがわかった。しかし $\mathrm{Ca}^{2+}$ 添 加下の加熱では，いずれの場合にも熱凝固が起こり，生 卵白の凍結融解法も有効な手段でないことが判明した。

\section{2 液混合型の経渴栄菱绪の調慗}

前実験より, $\mathrm{Ca}^{2+}$ を添加してもオートクレーブを 20 分以上施した $\mathrm{TEW}$ 液は $\mathrm{pH} 7.0$ 下でも凝集物が生じ ないことが見いたされた。すなわち $\mathrm{Ca}^{2+}$ と TEW 液を 混合しても加熱しなければ凝集物が生じないことより， あらかじめ卵白成分とミネラル成分とを別々に加熱殺菌 し，冷後混合すると凝集物が生じないものと考えられ る。そこで 2 液混合型の経腸栄堆羭の調製法を検討し た。その結果，A，B液からなる混合物を調製した (Table 3)。すなわち，A夜には $5 \%$ TEW 液（20 分 のオートクレーブ処理後 2 倍に減圧瀑縮を行なったむ の）と，ビタミン混合物")を添加後，オートクレーブ （5分）による隇菌を行なった。一方，B液には煻質 (米デキストリン), 脂質 (米油)， $\mathrm{Na}^{+}, \mathrm{Ca}^{2+}$ K加え, さらに $\mathrm{K}^{+}, \mathrm{Mg}^{2+}$ を添加し, $100 \mathrm{ml}$ としてオートクレ ーブ 10 分を行なった。これらのA， B液を使用時に混 合すると透明な経腸栄養剤が得られた。以上の栄羕剂 $400 \mathrm{ml}$ 中に固型物は $98.2 \mathrm{~g}$ （タンパク質 $15.0 \mathrm{~g}$, 糖質 $70.1 \mathrm{~g}$, 脂質 $9.3 \mathrm{~g}$ ，ミネラル $2.8 \mathrm{~g}$, ビタミン $1.0 \mathrm{~g}$ ) 含有され，熱量は $424 \mathrm{kcal}$, PFC 比は $14: 20: 66$ で ある。したがってほぼ理想食に近い栄養㓦といえる。

\section{3. 全混合型の释腸栄意都の検討}

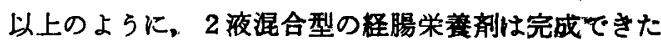


Table 2. Effect of thawing temperature of frozen egg white on thermal coagulation.

\begin{tabular}{|c|c|c|c|c|c|c|c|}
\hline \multirow{2}{*}{$\begin{array}{l}\text { Thawing } \\
\text { temperature } \\
\left({ }^{\circ} \mathrm{C}\right)\end{array}$} & & \multicolumn{3}{|c|}{ pH 9.0} & \multicolumn{3}{|c|}{$\mathrm{pH} 7.0$} \\
\hline & & Control & $\mathrm{Ca}^{2+*}$ & $\mathrm{Ca}^{2+}\left(100^{\circ} \mathrm{C}\right)^{* *}$ & Contro & $\mathrm{Ca}^{2+*}$ & $\mathrm{Ca}^{2+}\left(100^{\circ} \mathrm{C}\right)^{* *}$ \\
\hline \multirow[t]{5}{*}{$\mathrm{H}_{2} \mathrm{O}$ treatment } & 4 & - & - & \pm & - & - & + \\
\hline & 10 & - & - & \pm & - & - & + \\
\hline & 20 & - & - & \pm & - & \pm & + \\
\hline & 30 & - & - & \pm & - & \pm & + \\
\hline & 40 & - & - & \pm & - & \pm & + \\
\hline \multirow[t]{5}{*}{ EtOH treatment } & 4 & - & - & \pm & - & \pm & + \\
\hline & 10 & - & - & \pm & - & - & + \\
\hline & 20 & - & - & \pm & - & \pm & + \\
\hline & 30 & - & - & \pm & - & \pm & + \\
\hline & 40 & - & - & \pm & - & \pm & + \\
\hline
\end{tabular}

* $\mathrm{CaCl}_{2}$ was added to the solution.

** $\mathrm{CaCl}_{2}$ was added to the solution and heated at $100^{\circ} \mathrm{C}$ for $5 \mathrm{~min}$.

The fresh egg white $(500 \mathrm{ml})$ was divided into five parts and frozen in a stocker at $-20^{\circ} \mathrm{C}$. It was then thawed at different temperature from 4 to $40^{\circ} \mathrm{C}$, and used for the thermal coagulation test. The experiments were carried out in the same way as shown in Table 1.

Table 3. Utilization of non-thermal-coagulating egg white solution for enteral hyperalimentation.

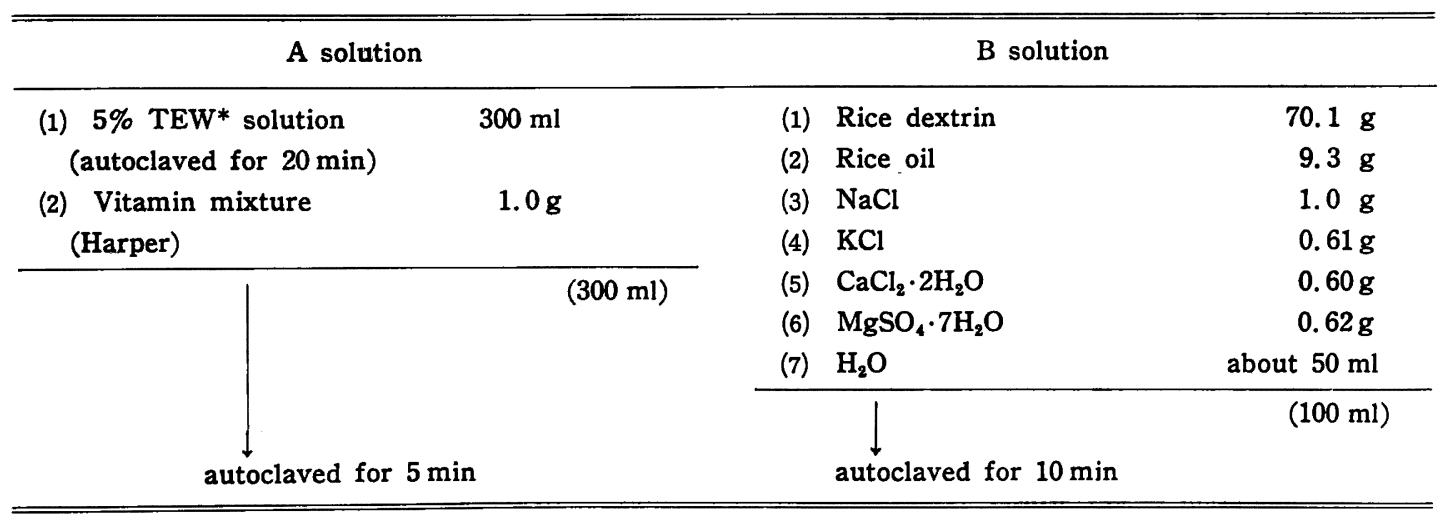

$\mathrm{A}+\mathrm{B} \longrightarrow$ Enteral hyperalimentation.

A solution, the egg white $(150 \mathrm{ml})$ was diluted with $600 \mathrm{ml}$ of water, filtered and autoclaved for 20 min. The protein solution was condensed by evaporation by two times (5\% protein). This condensed solution and vitamin mixture were mixed and autoclaved for $5 \mathrm{~min}$.

B solution, rice dextrin, rice oil, $\mathrm{NaCl}, \mathrm{KCl}, \mathrm{CaCl}_{2} \cdot 2 \mathrm{H}_{2} \mathrm{O}$ and $\mathrm{MgSO}_{4} \cdot 7 \mathrm{H}_{2} \mathrm{O}$ were thoroughly mixed and dissolved in water to a final volume of $100 \mathrm{ml}$ and the mixture was autoclaved for $10 \mathrm{~min}$.

$A$ and $B$ solutions were mixed after cooling.

ので，次に全混合型の経腸栄養凨の検討を試みた。全栄 賚成分を含む全混合型のものでは, TEW 液と $\mathrm{Ca}^{2+}$ の 存在下で熱凝固しないことが必須の条件である。そこで カルシウムイオン剤の種類を変えてその効果を検討し た。すなわち, 塩化カルシウム $\left(\mathrm{CaCl}_{2}\right)$ の代わりに, リ ン酸カルシウム $\left(\mathrm{Ca}\left(\mathrm{PO}_{4}\right)_{2}\right)$, 硫酸カルシウム $\left(\mathrm{CaSO}_{4}\right)$, リン酸水素カルシウム $\left(\mathrm{CaHPO}_{4}\right)$, リン酸二水素カルシ ウム $\left(\mathrm{Ca}\left(\mathrm{H}_{2} \mathrm{PO}_{4}\right)_{8}\right)$ ) パントテン酸カルシウム, グリセ口
リン酸カルシウムを用いて検討した。その結果, グリセ ロリン酸カルシウムがたいへん有効である事実を見いた した。Fig.1 はカルシウムの添加濃度と TEW 液のオー トクレーブ時間による奻果を検討したものであるが，オ ートクレーブ 0 分のものでは $100^{\circ} \mathrm{C}, 10$ 分の加熱で沈殹 物量が多く，1\%の添加まで直線的に增加したのに対 し, オートクレーブが10 分, 120 分の TEW 液では沈 殷物の生成は著しく低下した。この傾向は 120 分の 
Table 4. Effect of autoclaving time and $\mathrm{Ca}^{2+}$ on thermal coagulation.

\begin{tabular}{|c|c|c|c|c|c|c|}
\hline \multirow{3}{*}{\multicolumn{2}{|c|}{$\begin{array}{l}\text { Autoclaving } \\
\text { time } \\
\text { (min) }\end{array}$}} & \multicolumn{5}{|c|}{ Mineral $\mathrm{Ca}^{2+}$} \\
\hline & & \multirow{2}{*}{ Control } & \multicolumn{2}{|c|}{$\mathrm{CaCl}_{2}$} & \multicolumn{2}{|c|}{$\mathrm{C}_{3} \mathrm{H}_{7} \mathrm{O}_{6} \mathrm{P} \cdot \mathrm{Ca}$} \\
\hline & & & Preheating & Heating & Preheating & Heating \\
\hline \multirow[t]{2}{*}{20} & pH 9.2 & - & - & + & - & - \\
\hline & $\mathrm{pH} 7.0$ & - & - & + & - & \pm \\
\hline \multirow[t]{2}{*}{30} & pH 9.2 & - & - & + & - & - \\
\hline & $\mathrm{pH} 7.0$ & - & - & + & - & \pm \\
\hline \multirow[t]{2}{*}{60} & pH 9.2 & - & - & - & - & - \\
\hline & $\mathrm{pH} 7.0$ & - & - & + & - & - \\
\hline \multirow[t]{2}{*}{120} & pH 9.2 & - & - & - & - & - \\
\hline & pH 7.0 & - & - & + & - & - \\
\hline
\end{tabular}

Non-thermal-coagulating egg white solution was prepared by the way described in Table 1. The solution was adjusted to $\mathrm{pH} 9.2$ or 7.0 , and $\mathrm{CaCl}_{2}$ or calcium glycerophosphate was added to the solution. The results $(+,-)$ of TC test were judged by observing the turbidity as shown in Table 1.

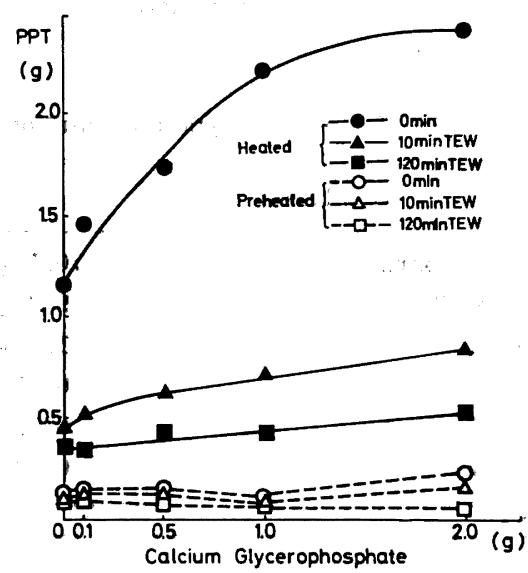

Fig. 1. The effect of $\mathrm{Ca}^{2+}$. on the thermal coagulation of egg white.

The egg white $(500 \mathrm{ml})$ was diluted with water by five fold, and filtered. The filtrate was divided into three parts and autoclaved for 0 $\mathrm{min}, 10 \mathrm{~min}$ or $120 \mathrm{~min}$, respectively. Three kinds of samples of TEW $(100 \mathrm{ml})$ were mixed with calcium glycerophosphate and heated at $100^{\circ} \mathrm{C}$ for $10 \mathrm{~min}$. The precipitate emerged was filtered, dried and weighed.

TEW 液でより顕著であった。そこで次に，塩化カルシ ウムとクリセロリン酸カルシウムの比較実験を試みた (Table 4)。その結果, 60 分以上のオートクレーブを行 なった TEW 液を $\mathrm{pH} 7.0$ に調製し, クリセロリン酸 カルシウム $\left(\mathrm{Ca}^{2+}: 0.05 \%\right)$ を添加し, 加熱してもまっ たく熱凝固は起こらなかった。したがってアニオン部分 の異なったカルシウム阂を用いることにより, 全混合型
Table 5. Effect of $\mathrm{Ca}^{2+}$ and $\mathbf{M g}^{2+}$ on thermal coagulation.

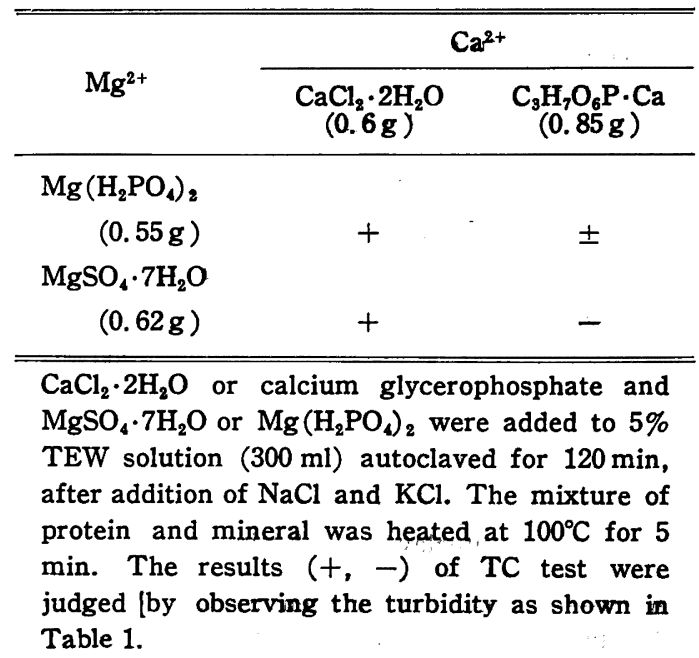

の経腸栄養㨈の調製が可能であるよらに思われた。そこ で次に, $\mathrm{Ca}^{2+}$ に加え, さらに $\mathrm{Mg}^{2+}$ の添加混合か;可能 かを検討した。Table 5 K示した量を添加し，熱凝固性 を調へたところ,クリセロリン酸カルシウムと硫酸マク ネシウムの組合せが最も卵白液を透明にすることが判明 した。そこで次に，Table 6 飞示す成分を混合し，全量 $400 \mathrm{ml}$ の溶液を 5 分間オートクレーブ娍 菌 し，長期間 保存可能で透明な経腸栄養郕が得られた。さらにこの 5 $\% \mathrm{TEW}$ 液を倲結乾燥佀より粉末化して, Table 7 に示 すような組成を混合することにより，粉末の経腸栄美標 品を得ることができた。本槚品は，サンブルA（脂肪入 り)ままは B（脂肪なし）の $100 \mathrm{~g}$ 飞水を加えて 400 
Table 6. Composition of enteral hyperalimentation (Solution).

\begin{tabular}{lr}
\hline \hline $\begin{array}{l}\text { (1) } 5 \% \text { TEW solution } \\
\text { (autocloved for } 120 \mathrm{~min} \text { ) }\end{array}$ & $300 \mathrm{ml}$ \\
(2) Rice dextrin & $70.1 \mathrm{~g}$ \\
(3) $\mathrm{Rice}$ oil or MCT & $9.3 \mathrm{~g}$ \\
(4) $\mathrm{NaCl}$ & $1.0 \mathrm{~g}$ \\
(5) $\mathrm{KCl}$ & $0.61 \mathrm{~g}$ \\
(6) $\mathrm{C}_{3} \mathrm{H}_{7} \mathrm{O}_{6} \mathrm{P} \cdot \mathrm{Ca}$ & $0.85 \mathrm{~g}$ \\
(7) $\mathrm{MgSO}_{4} \cdot 7 \mathrm{H}_{2} \mathrm{O}$ & $0.62 \mathrm{~g}$ \\
(8) Vitamin mixture & $1.0 \mathrm{~g}$ \\
(9) $\mathrm{H}_{2} \mathrm{O}$ & about $40 \mathrm{ml}$ \\
\hline \multicolumn{2}{c}{} \\
autoclaved for $5 \mathrm{~min}$ & total $400 \mathrm{ml}$ \\
\hline \hline
\end{tabular}

These nutrients were mixed and autoclaved for $5 \mathrm{~min}$, and the solution for enteral hyperalimentation was prepared.

ml とすると透明な溶液が得られた。以上の Table 6，7 の標品は Table 5 と同一カロリー, PFC 比をるつ高栄 養食品であり，細管チューブをむ通過した。

\section{考察}

現在の食品土業界ではタンパク質源として牛乳や大豆 が広く利用されている。一方，卵白は栄養価が高いにも かかわらず，その加工利用は著しく限定されている。著 者らはこの限定の主因が卵白のもつ強い熱凝固性にある と考之，本性質の完全消失についての研究を行ない，既 報1 3)のごとく本問題を解明することができた。そこで 今回は, 本非熱凝固性卵白 (TEW) 溶液の経腸栄養剤と しての利用性を検討した。経静脈栄養剤 ${ }^{102 ~ 12) ~}$ は血管中 飞直接栄着分を供給するものであり，タンバク質源とし ては抗原抗体反応を起こしやすい高分子のものは用いら れず，アミノ酸混合物といった低分子物質に限られる。

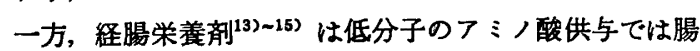
内の浸透压が過剩に高くなり，下浰を起こすといら不都 合が生じるため，胃または小腸を通す場合には高分子状 のタンパク質を供給する必要がある。また経管供与の患 者の負担を少なくするためには，チニーブをできるたけけ 細いものにすることが好ましい。このためには栄塊乳は 沈殿物がなく透明で，粘度の低いものが必要となる。そ こで以上の高分子性を維持することと，熱凝固しない透 明なものを得ることの 2 点を基本的項目として実験を試 みた。著者らの開発した従来の非熱凝固性卵白液は, 食 塩の存在 $(1 \% \mathrm{NaCl})$ によっても熱凝固しないが，カル シウム $\left(\mathrm{CaCl}_{2}\right)$ を添加すると強い熱凝固が起こった。
Table 7. Composition of enteral hyperalimentation (Powder).

\begin{tabular}{|c|c|c|c|}
\hline Nutrient & Sample & $\underset{(\mathrm{g} / 100 \mathrm{~g})}{\mathrm{A}}$ & $\stackrel{\mathrm{B}}{(\mathrm{g} / 100 \mathrm{~g})}$ \\
\hline Protein & $\begin{array}{l}\text { TEW powder } \\
\text { (autoclaved } \\
\text { for } 120 \mathrm{~min} \text { ) }\end{array}$ & 15.0 & 15.0 \\
\hline $\begin{array}{c}\text { Carbohy- } \\
\text { drate }\end{array}$ & Rice dextrin & 70.1 & 70.1 \\
\hline Lipid & Rice oil & 9.3 & - \\
\hline \multirow[t]{4}{*}{ Mineral } & $\mathrm{NaCl}$ & 1.0 & \multirow{3}{*}{3.08} \\
\hline & $\mathrm{KCl}$ & $\left.0.61\right|_{3.08}$ & \\
\hline & $\mathrm{C}_{3} \mathrm{H}_{7} \mathrm{O}_{6} \mathrm{P} \cdot \mathrm{Ca}$ & $0.85\}^{3.08}$ & \\
\hline & $\mathrm{MgSO}_{4} \cdot 7 \mathrm{H}_{2} \mathrm{O}$ & $0.62^{\prime}$ & $0.62^{f}$ \\
\hline Vitamin & $\begin{array}{l}\text { Vitamin } \\
\text { mixture }\end{array}$ & 1.0 & 1.0 \\
\hline Others & - & 1.52 & 1.52 \\
\hline
\end{tabular}

For sample $A$, all of the nutrients were mixed. For sample B, lipid was excluded from sample A. $100 \mathrm{~g}$ of sample $\mathrm{A}$ or $\mathrm{B}$ was added to water and made up to $400 \mathrm{ml}$ of solution.

本問題を解明するためには，(1)加熱時間を延長し，タン ハクク質の変性を進める，(2)TEW 液にタンパク質分解酵 素（protease）を働かせ，加水分解による低分子化を行 なら方法が基本的には考えられる。そこで，今回は高分 子性の維持を主目的として,オートクレーブ時間の延長 による解決策を検討した。まず，オートクレーブを 60 分以上行なった場合は, $\mathrm{pH} 9.0$ の条件下では $\mathrm{Ca}^{2+}$ $\left(\mathrm{CaCl}_{2}\right)$ の添加 $(0.05 \%)$ 後, 加熱しても熱凝固が起こ らなかったが，一般に食品に用いられる $\mathrm{pH}$ 領域である pH 7.0 では 120 分加熱のものでる熱疑固した。この結 果は, 水希釈の代わりにェタノール希釈を行なったり， 生卵白の凍結融解による変性を行なっても向上すること はなかった (Table 2)。しかし，20 分以上加熱したもの では pH 7.0 においても $\mathrm{Ca}^{2+}$ を添加しても凝集物が生 したり，沈殿物が生じたりしないことがかかり（Table 1), この性質を利用して 2 液混合型の経腸栄養剤の調製 を試みだっその結果, 卵白のタンパク質に加克, 糖質, 脂質, ピタミン，ミネラルの 5 大栄養素を含有する栄養 剤が A，B液の 2 液の混合により得られることが見いた された。次に一つの容器に 5 大栄養素が混合してある全 成分混合型の栄養㓮の調製法の検討を行なった。その結 果, 塩化カルシウムの代わりにクリセロリン酸カルシウ ムを用いると, 60 分以上の加熱の TEW 液は熱㠜固し ないことが見いだされ，卵白の熱凝固にはカチオンだけ でなくフニオンも大きく影響することがわかった。以上 の検討の結果, Table 6 に示すようにオートクレーブを 120 分した TEW 液 (5\%タンパ質),デキストリン, 
米油（またはMCT)，ミネラル，ビタミンを混合し，全 量 $400 \mathrm{ml}$ とし，5分間オートクレーブ減菌を行な5と 長期保存が可能な経腸栄盖溶液が得られることがわかっ た。本溶液は, $400 \mathrm{ml}$ 中に $424 \mathrm{kcal}$ の熱量を含み, PFC 比は, $14: 20: 66$ でほぼ理想的な成分割合である と考えられる。本液を 1 日 5 回， $2,000 \mathrm{ml}$ 领用すると， $2,120 \mathrm{kcal}$ ，タンパク質は $75 \mathrm{~g}$, 炭水化物は $350 \mathrm{~g}$, 脂肪 は $46 \mathrm{~g}$ 得られることになる。さらに TEW 粉末標品を 用いることにより，粉末の経腸栄義剈が得られ，これは 溶液標品と同じ栄養成分をもっている。以上のように, 前報》)で見いたされた非熱凝固性卵白溶液 (TEW) は経 腸栄養片として十分利用できることが明確となった。今 後は, 経腸栄養剤以外の食品中への本非熱凝固性卵白液 の利用が期待される。

要 約

非熱凝固性卵白液 (TEW) の経腸栄養剤としての利用 性を検討した。

1) 本 $\mathrm{TEW}$ 液は $\mathrm{NaCl}(1 \%)$ の添加では熱凝固し ないか， $\mathrm{CaCl}_{2}\left(\mathrm{Ca}^{2+}: 0.05 \%\right)$ の添加では熱凝固が起こ った。そこでTEW を調製する祭にオートクレーブ時間 を従来の 10 分から 60 分, 120 分にすると, $\mathrm{pH} \mathrm{9.0:で}$ は熱凝固しないことがわかった。しかし $\mathrm{pH} 7.0$ では 120 分オートクレーブしても依然，熱凝固した。

2）そこで $\mathrm{pH} 7.0$ 下で $\mathrm{Ca}^{2+}$ 添加後加熱に上る熱凝 固性の消失について検討したところ，水希釈法の代わり にェチルアルコール希积法を行なっても，また生卵白の 凍結融解変性処理を施しても効果はなかった。

3）一方, $\mathrm{pH} 7.0$ 下で $\mathrm{Ca}^{2+}$ を添加しても，あらか しめめートクレーブ 20 分以上した TEW 液は白濁しな かった。したがってタンパク夜成分と $\mathrm{Ca}^{2+}$ 成分をあら かじめ別々にオートクレーブ隇菌した 2 液混合型の経腸 栄養浏を調製した。

4) Ca イオン剤の種類を検討したところ，クリセ口 リン酸カルシウムを用いると， $\mathrm{pH} 7.0$ 下でオートクレ ーブ 60 分の TEW は熱凝固しなかった。したかっって本 $\mathrm{Ca}$ イオン剂を用いることにより，全混合型の経腸栄養 凨の調製が可能と思われ，調製したところ，透明な溶液 が得られた。さらに，TEW の粉末標品を用いることに
より粉末の経腸栄美夙が得られることがわかった。

5) 以上の結果より，本非熱凝固性卵白液は経腸栄蒦 剤として十分利用できることが明確となった。したがっ て, その他，卵飲料中微生物工業等飞も本液か昿く利用 できるものと思われる。

本研究を遂行するに当たり，終始ご瑫切なご指導を賜 わりまんた恩師，京都大学名誉教授満田久烜先生に心か らお礼申しあげます。また適切なご助言をいただきまし た甲子園大学教授河合文雄先生に感謝の意を表します。 なお, 本論文の要旨は第 38 回日本栄䖯・食䊓学会総会 において発表した。

\section{文献}

1）西川善之, 河合文雄, 満田久輝 : 栄食誌, 37, 129 (1984)

2）西川善之，河合文雄，満田久輝：栄食誌，37, 457 (1984)

3）西川善之，河合文雄，満田久輝 : 栄食誌, 38, 191 (1985)

4) Stadelman, W.J. : Egg Science and Technology (Stadelman, W.J. and Cotterill, O.J., eds.), Chap. 1 (1977), Avi Publishing Co., Inc. (Westport, Connecticut)（森田重広訳：卵の技 術之科学 (1979), 学空社 (東京))

5）佐藤 泰, 渡辺乾二 : 蛋白質 核酸 醭素, 23, 54 (1978)

6) 今井忠平 : 食品工学, 8, 57 (1976)

7) 中村 良: 化学と生物, 22, 523 (1984)

8) Shimada, K. and Matsushita, S. : Agric. Biol. Chem., 44, 637 (1980)

9) Harper, A.E. : J. Nutr., 68, 405 (1959)

10）近藤芳夫 : 榆液と栄養ジャーナル（特集：静脈栄 盖之経腸栄善の今日的視点)，3，399 (1981)

11) 岡田 正: 日本消化器外科学会誌, 13, 1297 (1980)

12) McGowan, J. and Fausto, N. : Biochem. J., 170,123 (1978)

13）小越章平，入汇氏康：輸液々栄美ジャーナル（特 集：静脈栄養と経腸栄養の今日的視点)， 3，427 (1981)

14）小山 真, 相場哲郎, 吉川和子 : 輸液と栄䧳ジャ ーナル（特集：静脈栄盖と経腸栄盖の今日的視 点) 3,430 (1981)

15) Kaminski, M.V. : Surg. Gynecol. Obset., 143, 12 (1976)

(昭和 60 年 3 月 11 日 受理) 